\title{
Port hinterland intermodal container flow optimisation with green concerns: a literature review and research agenda
}

\author{
Jasmine Siu Lee Lam* and Yimiao Gu \\ Division of Infrastructure Systems and Maritime Studies, \\ School of Civil and Environmental Engineering, \\ Nanyang Technological University, \\ N1, 50 Nanyang Avenue, 639798, Singapore \\ Fax:+6567910676 E-mail: sllam@ntu.edu.sg \\ E-mail: GUYI0005@e.ntu.edu.sg \\ *Corresponding author
}

\begin{abstract}
The closer link between ports and supply chain leads to a growing research area - port hinterland intermodal development. Focusing on the literature with mathematical models, the purpose of this paper is to categorise and analyse earlier research contributions on intermodal container flow optimisation, to identify the research trends and gaps, and to suggest future research directions. Results show that future research should focus on global intermodal container flow optimisation, addressing the approaches of ports integrating into such global intermodal chain taken green issues into account. There is substantial need for research addressing greening the intermodal network and sustainable development. Providing cost effective solutions alone in optimisation problem is rather traditional and one-sided. Those market players possessing commercially viable capabilities and also environmental responsibilities would gain a competitive advantage in future dynamic business environment. Bi-objective or multi-objective optimisation would be more suitable to actual situations.
\end{abstract}

Keywords: intermodal transportation; intermodal network; container flow optimisation; port; hinterland; supply chain; green concern; sustainable development.

Reference to this paper should be made as follows: Lam, J.S.L. and Gu, Y. (2013) 'Port hinterland intermodal container flow optimisation with green concerns: a literature review and research agenda', Int. J. Shipping and Transport Logistics, Vol. 5, No. 3, pp.257-281.

Biographical notes: Jasmine Siu Lee Lam is an Assistant Professor at Nanyang Technological University in Singapore. She is also Director of the MSc Maritime Studies Programme. Her research areas include maritime logistics, port economics and green supply chain management. She has widely published in international journals such as Industrial Marketing Management, International Journal of Shipping and Transport Logistics, Journal of Transport Geography, Transportation, and Transportation Research Part A. She is a member of the editorial review board of Journal of Supply Chain Management. She received the Best Paper Award in the International Association of Maritime Economists Annual Conference at Melbourne in 2006. 
Yimiao $\mathrm{Gu}$ is a $\mathrm{PhD}$ student at Nanyang Technological University in Singapore. Her current research interests mainly focus on intermodal optimisation under the scope of operations research and maritime supply chain integration. She has received her MS in Logistics from Nanyang Technological University. Before her Masters studies, she had three years' working experience in logistics in China.

\section{Introduction}

As operations in ports increase in their complexities and extensiveness, the role of ports has developed into one that is powerful enough to influence the performance of supply chains. This fact has been recognised and thus has resulted in increasing number of studies in analysing supply chain competitiveness in relation to ports. Hinterland being a key portion of the supply chain, there is also a close connection between hinterland connectivity and port performance. Some studies have shown a positive relationship between these two elements (Marlow and Paixao, 2003; Paixao and Marlow, 2003; Bichou and Gray, 2004; Rodrigue and Notteboom, 2009). Port, as a node in international intermodal chain, has to provide sustainable values to the chain in order to survive and thrive (Yap et al., 2006). Supply chains can achieve higher competitive advantage through efficiently integrated inland transportation by ports. It is through a collaborative effort within the supply chain that ports are able to deliver optimal performance and values to their customers. Thus the integration of ports into supply chains has become a basic requirement by shippers, and some inland shippers desire inland port services as their facilities (Harrington, 1991; Walter and Poist, 2003; Walter and Poist, 2004; Roso and Lumsden, 2010). It has been illustrated by some studies that concepts of supply chain when incorporated into port planning and management can enhance port performance (Carbone and Martino, 2003; Almotairi and Lumsden, 2009; Lam and Yap, 2011a). Relationship and types of collaboration between ports and supply chain nodes including inland transport connections have also been examined more extensively in recent studies (Lee and Song, 2008; Notteboom and Rodrigue, 2008; Fremont and Géographie, 2009).

The closer link between ports and supply chain leads to a growing research area port hinterland intermodal development, which is the focus of this study. Notteboom and Rodrigue (2005) revised the port spatial model by adding a new phase 'regionalisation'. The characteristic of the port regionalisation phase is port functional integration and even joint development with hinterland logistics platforms in order to shape a regional transportation network to meet the demands of global supply chains. Intermodality with inland terminals and associated transport corridors which are recognised as cornerstones in port regionalisation give incentives for gateway ports (maritime load centres) to expand their hinterland reach to the maximum in order to provide a seamless, synchronised and highly efficient integration between ocean shipping and inland transportation (Notteboom and Rodrigue, 2008; Rodrigue and Notteboom, 2009; Iannone and Thore, 2010). There is no consensus on the definition of intermodal freight transport (Bontekoning et al., 2004). Intermodal container transportation is a major component of intermodal freight transportation and can be defined as container transportation in multimodal chains which link the original nodes of consignors to the destination nodes of consignees in order to offer door-to-door service to customers (Barnhart and Laporte, 
2007). Container which was invented for standardisation and safety concern to avoid loss and damage of freight in the mid-1900s has been a powerful vector of intermodal integration, enabling maritime and land transportation modes to interconnect more effectively (Thill and Lim, 2010).

Therefore, intermodal development which can address integration and efficiency in facilitating cargo flow is fundamental. In addition to the economic perspective, intermodality with environmental concerns contributes to sustainable development and is increasingly preferable by stakeholders including shippers (Eng-Larsson and Kohn, 2012). Seaports linked with inland ports by railway especially double-stack train application, inland barge connections, employing foldable containers to tackle empty container repositioning issues and using shortest possible initial and final journeys by truck in intermodal container networks are being categorised into green profiles for sustainable development (Hayutha, 1991; Choong et al., 2002; Rahimi et al., 2008; Liao et al., 2009; Shintani et al., 2010).

Through quantifiable means, issues about container flow optimisation were examined by a number of earlier published contributions with increasing interest so far. Key concepts include 'Globalisation', 'Port regionalisation', 'Intermodality', 'Sustainable development' and 'Empty container repositioning' among others. After a thorough literature review, the authors uncover that there are an unexpectedly low number of research articles tackling intermodal container flow optimisation issues also with sustainable development concern. An earlier review by Macharis and Bontekoning (2004) did not include the environmental aspect and sea transportation or connection to ports. Hence it is timely and valuable to conduct a review on container flow optimisation research to cover a wider perspective and the latest development. This review paper aspires to present a holistic and detailed review about container flow optimisation issues with two main objectives. First is to classify research contributions in such issues according to different category labels as an informative guide for academics and practitioners, and another objective is to identify research trends and gaps thus recommend directions for future research, particularly focusing more on port hinterland intermodal development.

The paper is organised as follows. The next section describes the methodology for summarising and devising the overall review table. Section 3 presents the review table and sub-tables to provide a comprehensive analysis to illustrate the identified research trends and gaps, as well as addresses potential directions for future research. In Section 4, conclusions are drawn with research limitations enclosed.

\section{Review methodology}

In the following sections, the focus is on the literature relating to container flow optimisation with mathematical approaches. The scope is confined to those with intermodal connection. Those studies purely on shipping network design, routing and scheduling are excluded since they are outside the study focus of port hinterland intermodal container flow. The merit of this focus is to advance our understanding on the methodological aspect of the research topic. The study will also be able to provide a consistent and in-depth comparison among the research papers. Thus those studies only with qualitative analysis are not covered in the comparison. Within this scope of 
intermodal container optimisation with green concerns which will provide policy implication of integrative port hinterland development, some related keywords and strings are identified, such as: 'container network optimisation', 'intermodal container flow optimisation', 'multimodal cargo flow', 'container assignment' and 'green supply chain'. A search was conducted by specifying these keywords and strings which appear in both the abstract and the paper's main body using library databases (e.g., Web of Science, Science Direct, SciVerse Scopus, IEEE Xplore, etc.). Such search method allows us to cover the major established international journals and conference papers in logistics and transportation, as well as management science and operations management, including Operations Research, European Journal of Operational Research, Annals of Operations Research, OR Spectrum, Transportation Research (Parts A, B, D, E), Transportation Science, Journal of Transport Geography, Maritime Policy \& Management, Maritime Economics \& Logistics, Decision Support Systems, and other relevant journals. From these comprehensive sources, 49 most relevant journal articles and one conference paper about intermodal container flow optimisation problems have been selected and thoroughly examined which span forty years in chronological order from 1972 to 2012.

After reviewing the 50 research contributions, we differentiate and categorise them in a summary table based on 11 different elements, namely 'Empty container', 'Laden container', 'Sea leg in sea-land intermodal (SI)', 'Land leg in sea-land intermodal (LI) or Land leg and port related (LP)', 'Green concern', 'Geographical area of case study', 'Model', 'Model classification (stochastic/dynamic (A) or deterministic/static (B))', 'Objective', 'Algorithm' and 'Algorithm classification'. Explanations on these classification labels are as follows:

1 'Empty container' and 'Laden container' classify these 50 papers into groups, only with empty container optimisation, only with laden container optimisation, or concerning both.

2 Same as above, 'SI' and 'LI or LP' classify them into groups from the perspective of intermodal transport. Due to the scope of this review, all papers selected should be intermodal in nature. We can find out whether sea- or land-based intermodal transport is more researched.

3 'Green concern' highlights the papers with environmental efforts to reduce carbon footprint generated by container transport.

4 'Geographical area of case study' illustrates the territories of case study, from which one can be informed which areas have received more attention.

5 'Model', 'Model classification (stochastic/dynamic(A) or deterministic/static(B))', 'Objective', 'Algorithm' and 'Algorithm classification' classify these papers clearly according to mathematical model used, model classification, objective in the optimisation model, algorithm to solve the model and the algorithm's classification respectively.

These 11 classification elements are selected in order to illustrate the content and methodology of the articles comprehensively. The 50 papers followed the same structure with three components: 'Problem definition', 'Problem solving' and 'Numerical example'. Each component can be categorised by certain classification elements. 
'Problem definition' can be classified by the elements of 'Empty container', 'Laden container', 'SI', 'LI or only LP', and 'Green concern'. The 'Problem solving' component can be sorted by the elements: 'Model', 'Model classification (stochastic/dynamic (A) or deterministic/static (B))', 'Objective', 'Algorithm' and 'Algorithm classification'. 'Numerical example' uses different regions for case studies and hence we label it with 'Geographical area of case study'.

\section{Analysis for identifying research trends and gaps and directions for future research}

This section presents a comprehensive table (Table 1), in which we summarise and classify the selected 50 research contributions. The papers are listed in chronological order, indicating the evolution of intermodal container flow optimisation research over time. Each paper is documented in detail in this review which serves as an informative guide for researchers and practitioners interested in this area. Afterwards, five sub-tables (Table 2 to Table 6) are formulated to assist in analysing Table 1 thoroughly in terms of different perspectives.

\subsection{Overview of selected papers according to journal domains}

By using 'Logistics and transportation', 'Operations research/management' and 'Maritime' to classify domains of these selected 49 journal papers as shown in Table 2, we find that the domain of 'Logistics and transportation' has the largest share of $42.9 \%$ (21 papers), which indicates that container flow optimisation issues are in accordance with the editorial objectives of journals in the logistics and transportation domain. Such researches are also widely accepted by 'Operations Research/Management' and other journals. This study area is contemporary and popular receiving considerable attention from the international research community.

\subsection{Discussion according to research problem categories}

Table 3 is derived to help us explore the research gaps through categorising research problems and analysis perspectives. Row (1) combines 'SI' and 'LI' in Table 1, labelling as intermodal container transportation to differentiate such sea-land intermodal papers from the others. Likewise, Row (2) selects 'LP' only in Table 1, identifying those studies on land transport related to seaports to distinguish such papers from sea-land intermodal container transportation. Row (3) integrates 'Empty container' and 'Laden container' columns in Table 1 together to show which papers deal with the more complicated and realistic situation in optimising the flows of both laden containers and empty container repositioning. Row (4) is based on the 'Green concern' column in Table 1 to discover the insufficiency of environmental protection concern in container flow optimisation research. Based on the 'Objective' column in Table 1, Row (5) summarises such papers with two or more objectives as 'bi/multi-objective optimisation' scope. Finally, Row (6) joins the above five rows together to devise a research niche accordingly. 
Table 1 Summary and classification of literature on intermodal container transportation

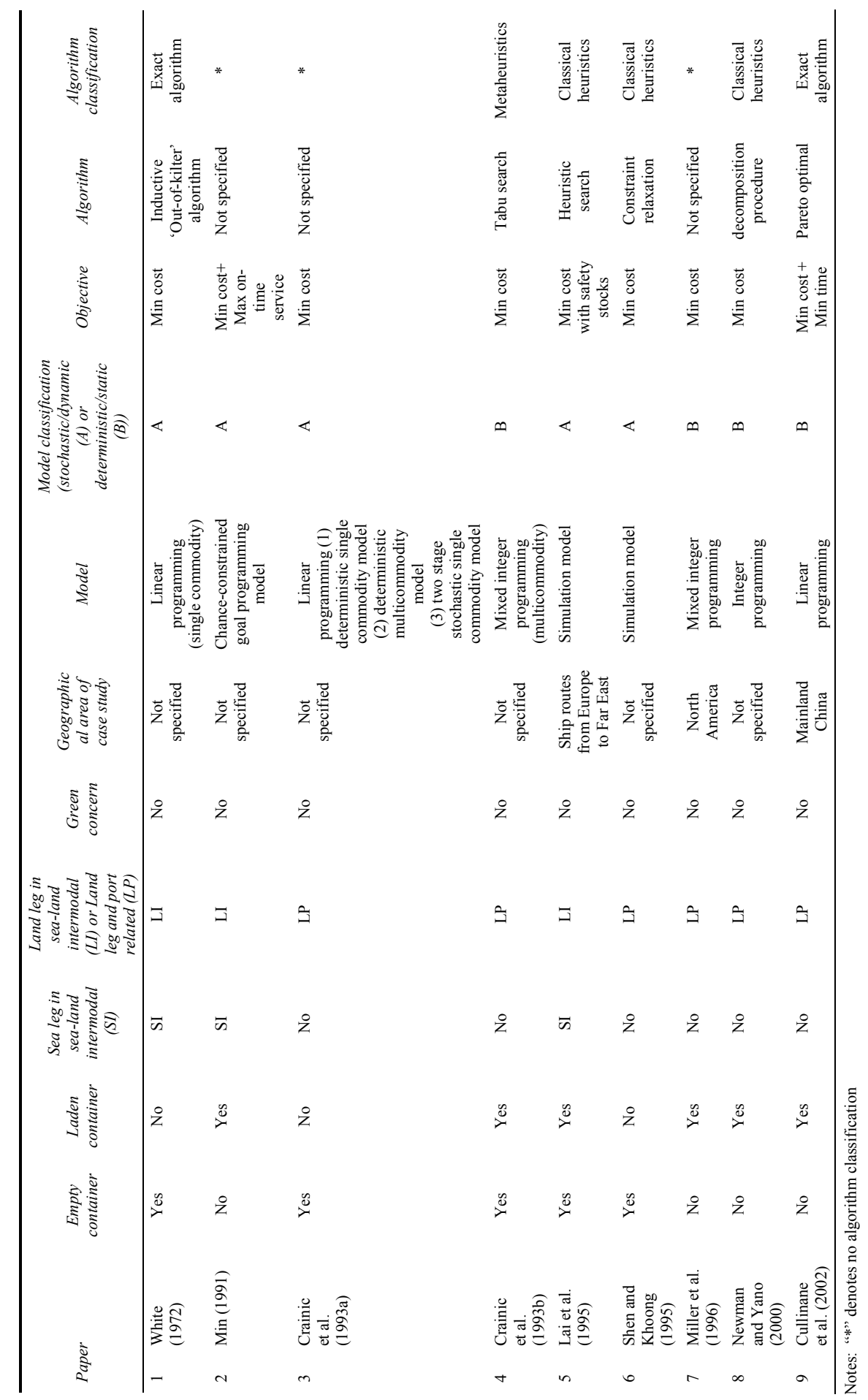


Table 1 Summary and classification of literature on intermodal container transportation (continued)

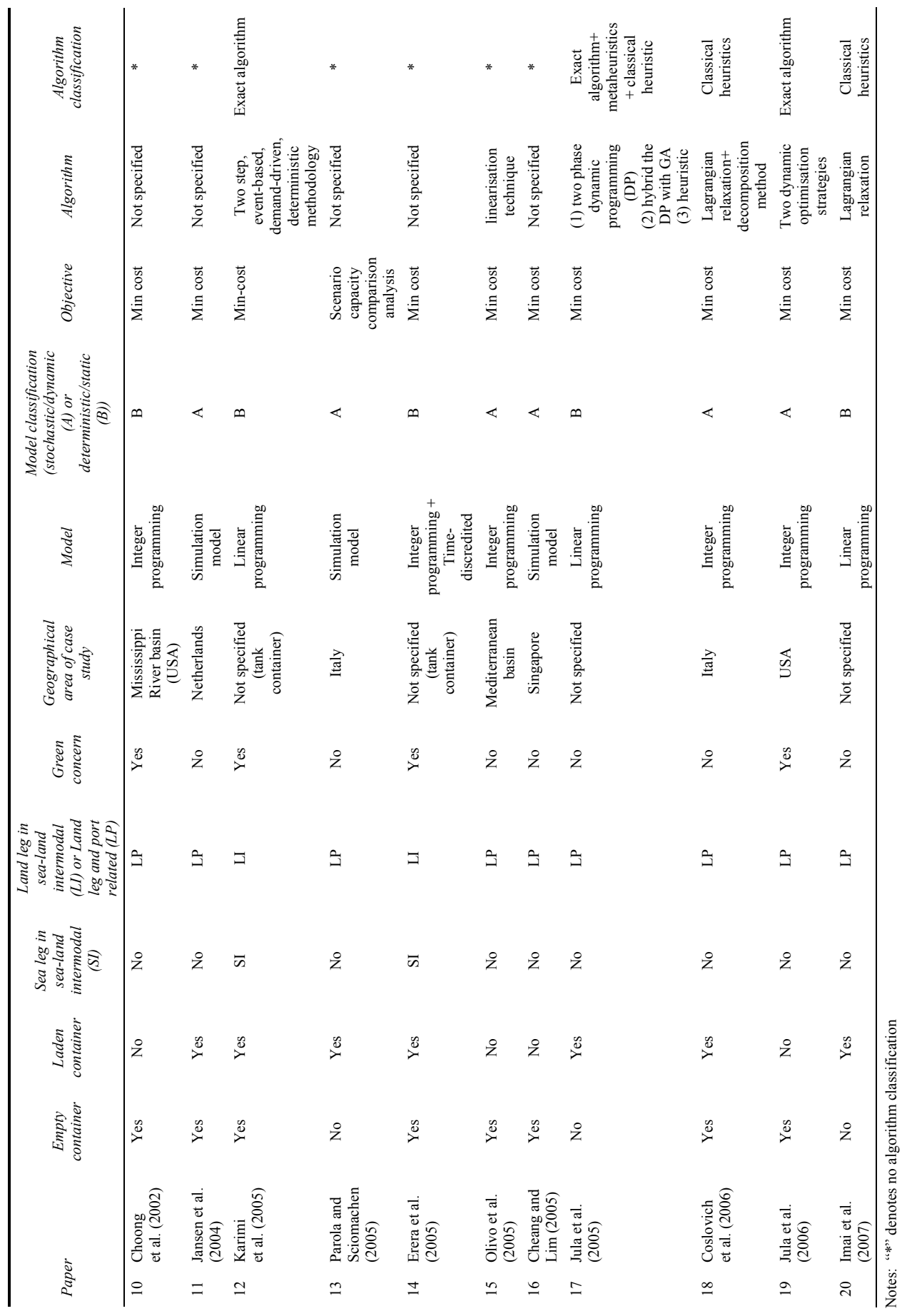


Table 1 Summary and classification of literature on intermodal container transportation (continued)

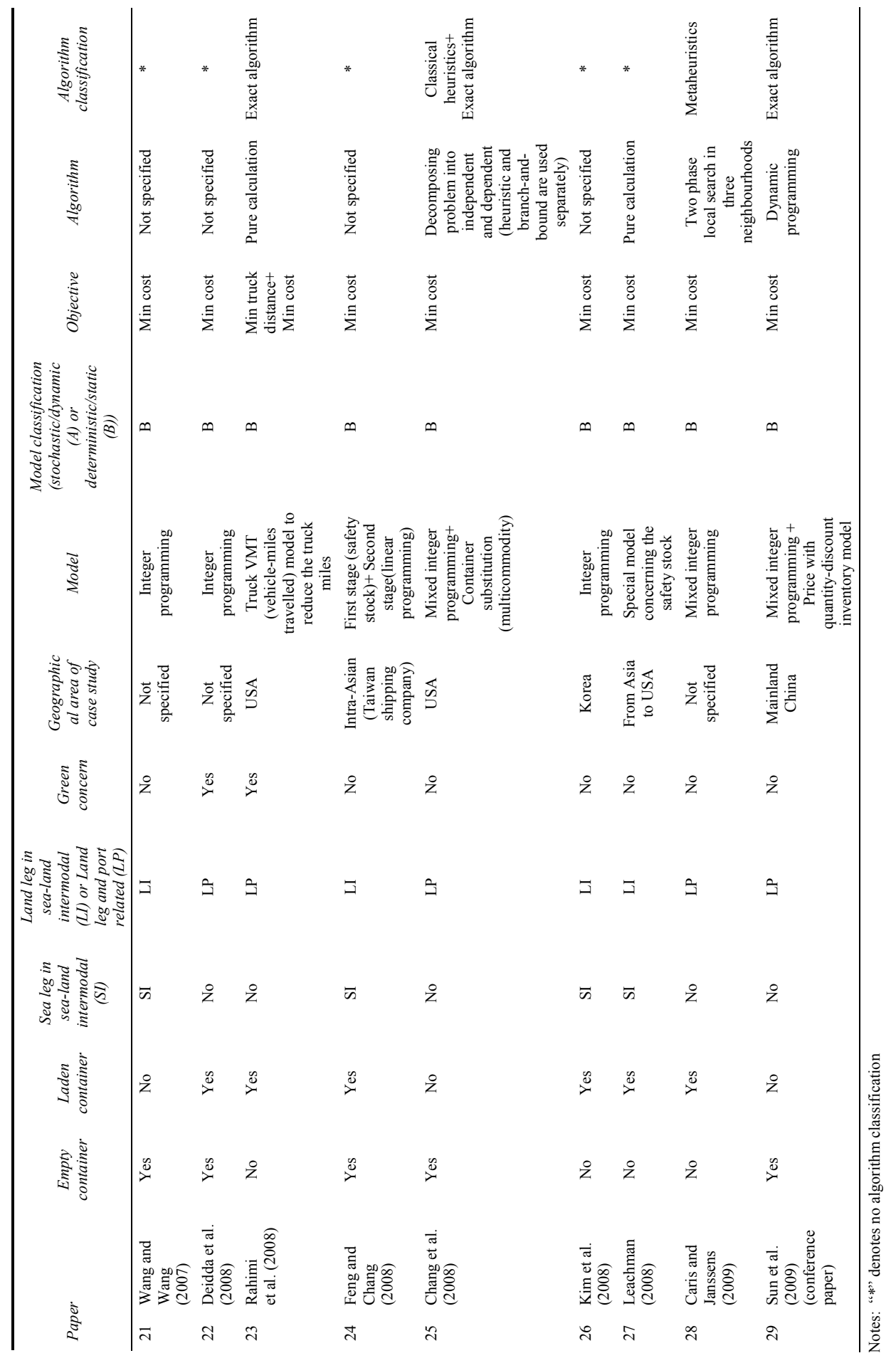


Table 1 Summary and classification of literature on intermodal container transportation (continued)

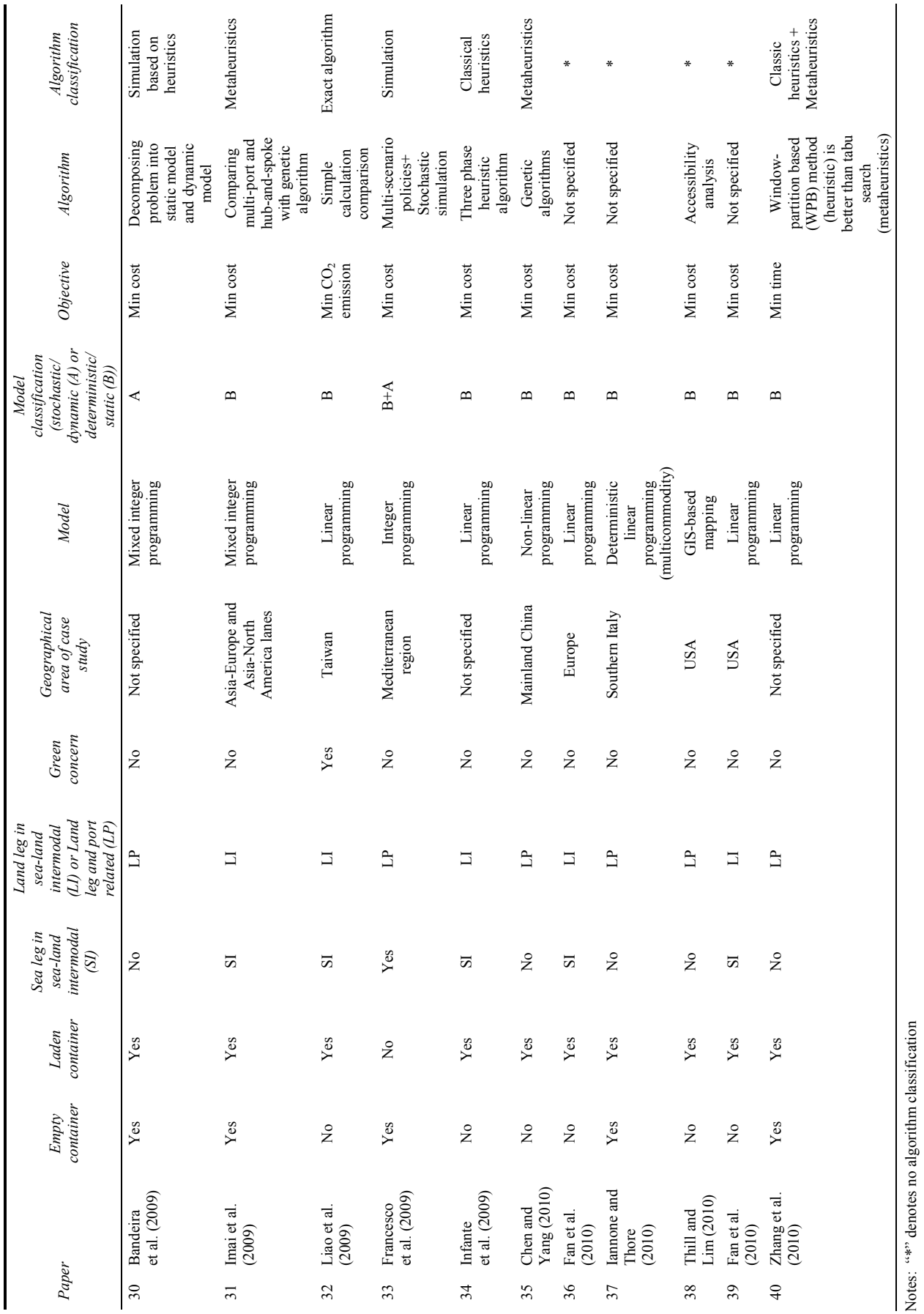


Table 1 Summary and classification of literature on intermodal container transportation (continued)

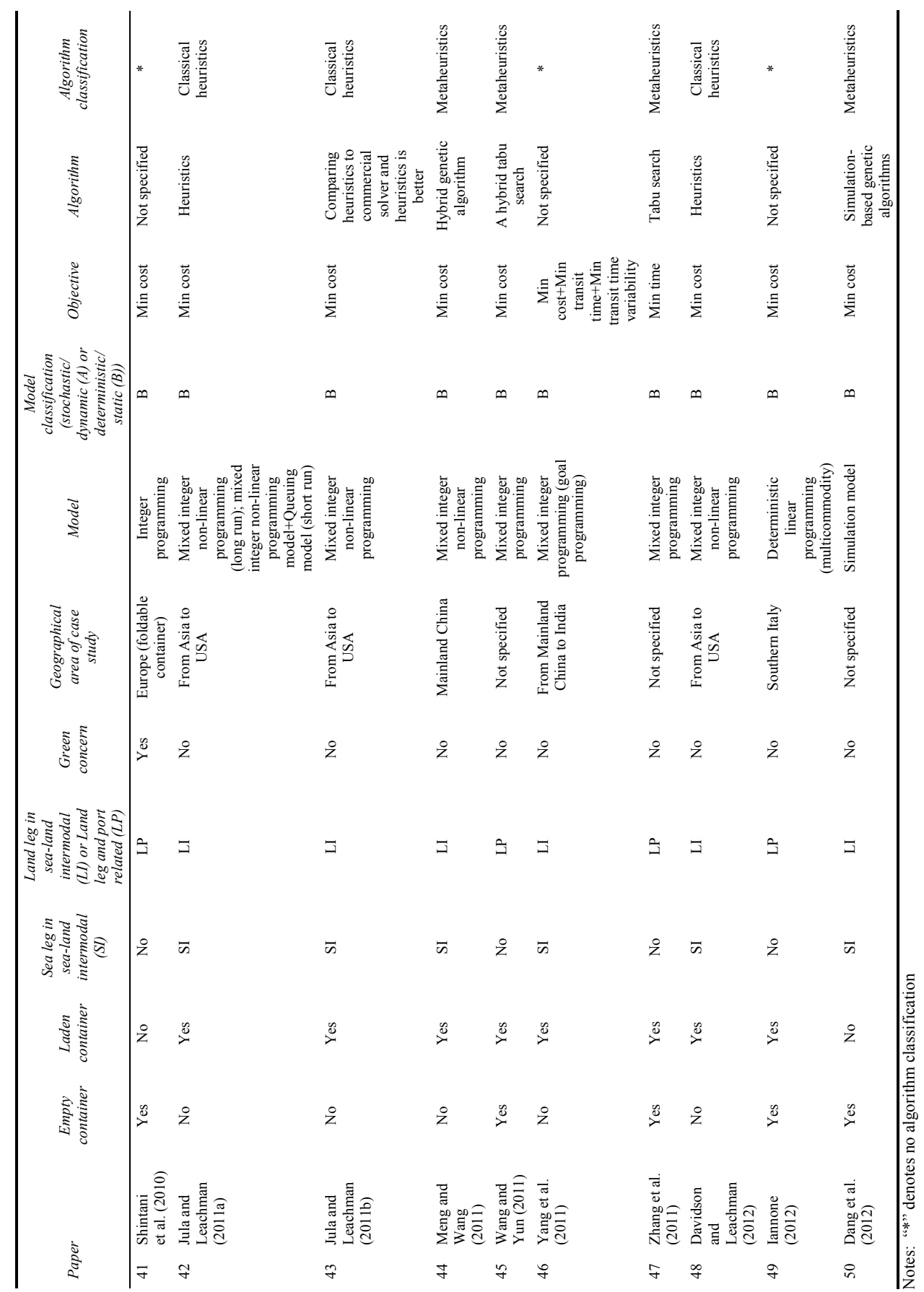


Table 2 Classification according to journal domains

\begin{tabular}{llc}
\hline $\begin{array}{l}\text { Journal domain } \\
\text { classification }\end{array}$ & \multicolumn{1}{c}{ Journals (totally 49 journal papers) } & $\begin{array}{c}\text { Number } \\
(\%)\end{array}$ \\
\hline Logistics and & Transportation Research Part A (1), Transportation & $21(42.9 \%)$ \\
transportation & Research Part B (1), Transportation Research Part & \\
& D (1), Transportation Research Part E (12), & \\
& Location Science (1), Transportation Science (1), & \\
& International Journal of Transport Economics (2), & \\
& Journal of Transport Geography (2) & \\
Operations & Networks (1), Operations Research (1), Annals of & $12(24.5 \%)$ \\
research/management & Operations Research (1), Journal of the & \\
& Operational Research Society (1), European \\
& Journal of Operational Research (3), International & \\
& Journal of Production Economics (3), OR Spectrum & \\
& (1), Computers \& Operations Research (1). & \\
Maritime & Maritime Policy \& Management (4), Maritime & $9(18.4 \%)$ \\
Other journals & Economics \& Logistics (5). & \\
& Decision Support Systems (2), AIChE Journal (1), & $7(14.3 \%)$ \\
& International Journal of Computer Applications in & \\
& Technology (1), Journal of Transportatiom Systems & \\
& Engineering and Information Technology (1), & \\
& Journal of Marketing Channels (1), Computers & \\
\&Industrial Engineering (1). & \\
\hline
\end{tabular}

In general terms, Rows (1) to (5) in Table 3 classify the selected research studies from five different analysis perspectives on the research issues and row (6) integrates these five perspectives to narrow down the research issue to 'Intermodal container flow considering both empty and laden containers with green concern using bi/multi-objective optimisation' as a research gap. No previous paper is found under this classification. Hence we conclude that this research area is under-represented with insufficient study, which would be attributed to the problem's higher level of complexity.

Although intermodal container transportation is increasingly important in practice as discussed in the Introduction section, most papers have examined only sea leg container transportation or only land leg container transportation optimisation thus far. Research involving a larger span of the supply chain with both sea and land transportation optimisation is quite limited with only $20(40 \%)$ papers among the 50 papers. Seaport, as an essential interface, links up these two separate networks together to shape an international/regional intermodal container network. In traditional concept, port is a node in seaborne network while voyage between two nodes carried out by ships is called an arc in such a network (Imai and Rivera, 2001). Under this background, academic researches focus on container network optimisation issues in sailing voyages. However, port is obliged to enter the new stage of regionalisation which is driven by market demand. Integrative intermodal transportation and port regionalisation development conform to market demand, thus more efforts should be made to tackle such sea-land intermodal optimisation issues.

In recent years, research articles which concern environmental protection are still relatively limited, although progressively increasing. There are only eight papers (16\%) classified into the 'With green concern' category with the aim to cut down carbon 
footprint. Research involves using greener modes of transportation like inland barge connections and innovative solutions such as double-stack train application and employment of foldable containers. Future research about intermodal container flow optimisation issues should be embedded with green concern to keep pace with the times and regulatory requirements to protect our planet. Noting this imminent trend, those ports and transport providers which can be both commercially viable and environmentally responsible would gain a competitive edge.

Table 3 Classification according to research problem categories

\begin{tabular}{|c|c|c|c|}
\hline \multicolumn{2}{|r|}{ Research problem categories } & \multirow[b]{2}{*}{$\begin{array}{l}\text { Papers (totally selected 50 papers) } \\
\text { 1, White (1972), 2, Min (1991), 5, Lai et } \\
\text { al. (1995), 12, Karimi et al. (2005), } \\
\text { 14, Erera et al. (2005), 21, Wang and } \\
\text { Wang (2007), 24, Feng and Chang (2008), } \\
\text { 26, Kim et al. (2008), } \\
\text { 27, Leachman (2008), 31, Imai et al. } \\
\text { (2009), 32, Liao et al. (2009), 34, Infante } \\
\text { et al. (2009), 36, Fan et al. (2010), } \\
\text { 39, Fan et al. (2010), 42, Jula and } \\
\text { Leachman (2011a), 43, Jula and Leachman } \\
\text { (2011b), 44, Meng and Wang (2011) 46, } \\
\text { Yang et al. (2011), 48, Davidson and } \\
\text { Leachman (2012), 50, Dang et al. (2012). }\end{array}$} & \multirow{2}{*}{$\begin{array}{c}\begin{array}{c}\text { Number } \\
(\%)\end{array} \\
20(40 \%)\end{array}$} \\
\hline 1 & $\begin{array}{l}\text { Concerning intermodal freight } \\
\text { transportation [both sea leg (SI) } \\
\text { and land leg (LI)] }\end{array}$ & & \\
\hline 2 & $\begin{array}{l}\text { Concerning land leg and port } \\
\text { related (LP) }\end{array}$ & $\begin{array}{l}\text { 3, Crainic et al. (1993a), 4, Crainic et al. } \\
\text { (1993b), 6, Shen and Khoong (1995), } \\
\text { 7, Miller et al. (1996), 8, Newman and } \\
\text { Yano (2000), 9, Cullinane et al. (2002), } \\
\text { 10, Choong et al. (2002), 11, Jansen et al. } \\
\text { (2004), 13, Parola and Sciomachen (2005), } \\
\text { 15, Olivo et al. (2005), } \\
\text { 16, Cheang and Lim (2005), 17, Jula et al. } \\
\text { (2005), 18, Coslovich et al. (2006), 19, } \\
\text { Jula et al. (2006), 20, Imai et al. (2007), } \\
\text { 22, Deidda et al. (2008), } \\
\text { 23, Rahimi et al. (2008), 25, Chang et al. } \\
\text { (2008), 28, Caris and Janssens (2009), 29, } \\
\text { Sun et al. (2009) (conference paper), 30, } \\
\text { Bandeira et al. (2009), 33, Francesco et al. } \\
\text { (2009), 35, Chen and Yang (2010), 37, } \\
\text { Iannone and Thore (2010), 38, Thill and } \\
\text { Lim (2010), 40, Zhang et al. (2010), } \\
\text { 41, Shintani et al. (2010), 45, Wang and } \\
\text { Yun (2011), 47, Zhang et al. (2011), } \\
\text { 49, Iannone (2012). }\end{array}$ & $30(60 \%)$ \\
\hline 3 & $\begin{array}{l}\text { Concerning both empty and } \\
\text { laden container transportation }\end{array}$ & $\begin{array}{l}\text { 4, Crainic et al. (1993b), 5, Lai et al. } \\
\text { (1995), 11, Jansen et al. (2004), } \\
\text { 12, Karimi et al. (2005), 14, Erera et al. } \\
\text { (2005), 18, Coslovich et al. (2006), } \\
\text { 22, Deidda et al. (2008), 24, Feng and } \\
\text { Chang (2008), 30, Bandeira et al. (2009), } \\
\text { 31, Imai et al. (2009), 37, Iannone and } \\
\text { Thore (2010), 40, Zhang et al. (2010), 45, } \\
\text { Wang and Yun (2011), 47, Zhang et al. }\end{array}$ & $15(30 \%)$ \\
\hline
\end{tabular}


(2011), 49, Iannone (2012).

Table 3 Classification according to research problem categories (continued)

\begin{tabular}{|c|c|c|c|}
\hline \multicolumn{2}{|c|}{ Research problem categories } & \multirow{2}{*}{$\begin{array}{l}\text { Papers (totally selected } 50 \text { papers) } \\
\text { 10, Choong et al. (2002), 12, Karimi et al. } \\
\text { (2005), 14, Erera et al. (2005), } \\
\text { 19, Jula et al. (2006) 22, Deidda et al. } \\
\text { (2008), 23, Rahimi et al. (2008), 32, Liao } \\
\text { et al. (2009), 41, Shintani et al. (2010). }\end{array}$} & \multirow{2}{*}{$\begin{array}{c}\begin{array}{c}\text { Number } \\
(\%)\end{array} \\
8(16 \%)\end{array}$} \\
\hline 4 & With green concern & & \\
\hline 5 & $\mathrm{Bi} /$ multi-objective optimisation & $\begin{array}{l}\text { 2, Min (1991), 9, Cullinane et al. (2002), } \\
\text { 23, Rahimi et al. (2008), 46, Yang et al. } \\
\text { (2011). }\end{array}$ & $4(8 \%)$ \\
\hline 6 & $\begin{array}{l}\text { Intermodal container flow } \\
\text { considering both empty and } \\
\text { laden containers with green } \\
\text { concern using bi/multi- } \\
\text { objective optimisation }\end{array}$ & None. & $0(0 \%)$ \\
\hline
\end{tabular}

Most research papers focus only on single-objective optimisation. The share of papers with bi/multi-objective optimisation is $8 \%$ (4 papers). It is observed that most selected papers concern cost optimisation only. However, to deal with practical problems, attention should also be paid on time consumption, carbon footprint and time variation. Hence multi-objective optimisation would have wider application in upcoming optimisation models to consider trade-offs among multiple objectives. In the diversified markets of today, including merely cost objective in optimisation model is insufficient since some customers require a fast and on time delivery service with less carbon footprint such as those adopting environmental policies as part of the business strategy and shippers transporting products with higher value and demand uncertainty like computers (Eng-Larsson and Kohn, 2012).

\subsection{Analysis according to mathematical models}

Turning to research methodology, Table 4 illustrates that there are three main classifications on the type of mathematical models in this domain, which are: linear model (35 papers or $70 \%$ ), non-linear model (5 papers or $10 \%$ ) and simulation model (6 papers or 12\%). Under the classification of 'Linear model', there are three subdivisions: linear programming (LP) (14 papers), integer programming (IP) (11 papers) and mixed integer programming (MIP) (10 papers). Among them, LP is more popular with higher frequency of occurrence. LP is a mathematical method for determining a way to achieve the best outcome (such as maximum profit or lowest cost) in a given mathematical model for some requirements represented as linear relationships. More formally, LP is a technique for the optimisation of a linear objective function, subject to 
linear equality and linear inequality constraints. If the unknown variables are all required to be integers, then the problem is called an IP. If only some of the unknown variables are required to be integers, then the problem is called an MIP problem. The decision to use LP, IP or MIP may depend on the scale of the problem and the authors' preferences. Generally speaking, if the variable which represents the quantity of container has a high order, such as $1,000,000$, there is no significant difference between 1,000,000 and $1,000,000.5$. Hence the decision variables about container numbers in large scale problem could be fractional values. However, the nature of container quantity should be integer value. Different authors have different preferences and designs on their model selection. For example, Iannone (2012) applies an LP model in his paper, while Shintani et al. (2010) design an IP model to fix their problem, even the problem scales are very similar. When some papers use binary variables $(0$ or 1$)$ or some papers involve both vehicle quantity (integer value) and container quantity (fractional value) in their models, MIP models are employed. Beside linear model, non-linear model and simulation model are also created to present some cases which do not exhibit linear characteristics or have a more dynamic relationship. Which model would be applied depends on the actual problems to be solved. Together with Table 1, our review provides a technical reference for researchers in considering the applicability of various models.

According to another classification about the mathematical model, among the selected 50 papers, 13 papers are included in A (dynamic/stochastic) while 37 papers are counted in B (deterministic/static). The dynamic/stochastic math model is more suitable for container flow optimisation problem according to its dynamic nature. However, dynamic/stochastic math models are often difficult to solve. This explains why a much lower percentage (26\%) of studies attempted the stochastic approach.

Table 4 Classification according to mathematical models

\begin{tabular}{llc}
\hline $\begin{array}{l}\text { Model classification I (linear, } \\
\text { non-linear or simulation) }\end{array}$ & \multicolumn{1}{c}{ Papers (totally selected 50 papers) } & $\begin{array}{c}\text { Number } \\
\text { (\%) }\end{array}$ \\
\hline $1 \quad$ Linear model & & $35(70 \%)$ \\
Linear programming & 1, White (1972), 3, Crainic et al. (1993a), & $14 / 35$ \\
& 9, Cullinane et al. (2002), 12, Karimi et al. & \\
& (2005), 17, Jula et al. (2005), 20, Imai et al. & \\
& et al. (2009), 34, Infante et al. (2009), 36, Fan & \\
et al. (2010), 37, Iannone and Thore (2010), & \\
& 39, Fan et al. (2010), 40, Zhang et al. (2010), & \\
& 49, Iannone (2012). \\
& 8, Newman and Yano (2000), 10, Choong et & $11 / 35$ \\
& al. (2002), 14, Erera et al. (2005), 15, Olivo et & \\
al. (2005), 18, Coslovich et al. (2006), & \\
Integer programming & (2007), 22, Deidda et al. (2008), 26, Kim et al. & \\
& (2008), 33, Francesco et al. (2009), & \\
& 41, Shintani et al. (2010). \\
& 4, Crainic et al. (1993b), 7, Miller et al. & $10 / 35$ \\
& (1996), 25, Chang et al. (2008), 28, Caris and & \\
Mixed integer & Janssens (2009), 29, Sun et al. (2009), & \\
programming & 30, Bandeira et al. (2009), 31, Imai et al. \\
& (2009), 45, Wang and Yun (2011), 46, Yang & \\
& et al. (2011), 47, Zhang et al. (2011). &
\end{tabular}


2 Non-linear model

35, Chen and Yang (2010), 42, Jula and

Table 4 Classification according to mathematical models (continued)

\begin{tabular}{|c|c|c|c|}
\hline \multicolumn{2}{|c|}{$\begin{array}{l}\text { Model classification I (linear, } \\
\text { non-linear or simulation) }\end{array}$} & \multirow{2}{*}{$\begin{array}{l}\text { Papers (totally selected 50 papers) } \\
\text { 5, Lai et al. (1995), 6, Shen and Khoong } \\
\text { (1995), 11, Jansen et al. (2004), 13, Parola and } \\
\text { Sciomachen (2005), 16, Cheang and Lim } \\
\text { (2005), 50, Dang et al. (2012). }\end{array}$} & \multirow{2}{*}{$\begin{array}{c}\begin{array}{c}\text { Number } \\
(\%)\end{array} \\
6(12 \%)\end{array}$} \\
\hline 3 & Simulation model & & \\
\hline 4 & Other models & $\begin{array}{l}\text { 2, Min (1991), 23, Rahimi et al. (2008), } \\
\text { 27, Leachman (2008), 38, Thill and Lim } \\
(2010) .\end{array}$ & $4(8 \%)$ \\
\hline \multicolumn{2}{|c|}{$\begin{array}{l}\text { Model classification II } \\
\text { (dynamic/stochastic or } \\
\text { deterministic/static) }\end{array}$} & Papers (totally selected 50 papers) & $\begin{array}{c}\text { Number } \\
(\%)\end{array}$ \\
\hline & $\begin{array}{l}\text { Dynamic/stochastic (A) } \\
\text { model }\end{array}$ & $\begin{array}{l}\text { 1, White, (1972), 2, Min, (1991), 3, Crainic et } \\
\text { al. (1993a), 5, Lai et al. (1995), 6, Shen and } \\
\text { Khoong (1995), 11, Jansen et al. (2004), } \\
\text { 13, Parola and Sciomachen (2005), 15, Olivo } \\
\text { et al. (2005), 16, Cheang and Lim (2005), } \\
\text { 18, Coslovich et al. (2006), 19, Jula et al. } \\
\text { (2006), 30, Bandeira et al. (2009), } \\
\text { 33, Francesco et al. (2009). }\end{array}$ & $13(26 \%)$ \\
\hline & $\begin{array}{l}\text { Deterministic/static (B) } \\
\text { model }\end{array}$ & $\begin{array}{l}\text { 4, Crainic et al. (1993b), 7, Miller et al. } \\
\text { (1996), 8, Newman and Yano (2000), } \\
\text { 9, Cullinane et al. (2002), 10, Choong et al. } \\
\text { (2002), 12, Karimi et al. (2005), 14, Erera et } \\
\text { al. (2005), 17, Jula et al. (2005), 20, Imai et al. } \\
\text { (2007), 21, Wang and Wang (2007), } \\
\text { 22, Deidda et al. (2008), 23, Rahimi et al. } \\
\text { (2008), 24, Feng and Chang (2008), } \\
\text { 25, Chang et al. (2008), 26, Kim et al. (2008), } \\
\text { 27, Leachman (2008), 28, Caris and Janssens } \\
\text { (2009), 29, Sun et al. (2009), 31, Imai et al. } \\
\text { (2009), 32, Liao et al. (2009), 33, Francesco et } \\
\text { al. (2009), 34, Infante et al. (2009), 35, Chen } \\
\text { and Yang (2010), 36, Fan et al. (2010), } \\
\text { 37, Iannone and Thore (2010), 38, Thill and } \\
\text { Lim (2010), 39, Fan et al. (2010), 40, Zhang } \\
\text { et al. (2010), 41, Shintani et al. (2010), } \\
\text { 42, Jula and Leachman (2011a), 43, Jula and } \\
\text { Leachman (2011b), 44, Meng and Wang } \\
\text { (2011), 45, Wang and Yun (2011), 46, Yang } \\
\text { et al. (2011), 47, Zhang et al. (2011), } \\
\text { 48, Davidson and Leachman (2012), } \\
\text { 49, Iannone (2012), 50, Dang et al. (2012). }\end{array}$ & $37(74 \%)$ \\
\hline
\end{tabular}




\subsection{Analysis according to algorithms}

After analysing the type of mathematical models, which algorithm would be proposed and used to solve the model can be addressed in Table 5. Exact algorithms are usually proposed to solve instances involving limited variables and power degree (vertices). But in some real cases, when the size of vertices exceeds the limitation, heuristics algorithms would be the preferred algorithms to be utilised especially with metaheuristics's recent powerful and speedy development. Simulation method is used in such cases as a last resort when exact algorithm or heuristic algorithm is not applicable to get the optimal solution or sub-optimal solutions especially in some stochastic problems. But simulation method cannot find an optimal solution and is not inherently an optimisation tool. It is often the only means to approach complex systems analysis.

Here, we highlight the difference between 'classical heuristics' and 'metaheuristics'. 'Classical heuristics' does not have any mechanisms to allow the objective function changing from one iteration to the next one while 'metaheuristics' owns these mechanisms on the contrary. Metaheuristic algorithm is a heuristic method to solve computation problems using black-box procedures in a more efficient way. Metaheuristic algorithms are used for combinatorial optimisation in which an optimal solution is sought over a discrete search-space. Popular and common metaheuristic algorithms for combinatorial optimisation problems include simulated annealing, tabu search, genetic algorithms and ant colony optimisation (Yang, 2008).

From the algorithm classifications in Table 5, there is no conclusion suggesting which algorithm is more prevailing than others. Which algorithm would be approached depends on the scale and difficulty level of the given math model. If the scale of the given math model is not so large, it can be solved through designing exact algorithm to get the optimal solution. Although exact algorithm can only solve relatively small scale problems, $14 \%$ of the papers create some sophisticated exact algorithms to increase the difficulties and contributions of their research. Exact algorithm is more challenging in a mathematical sense, which means higher sophistication from the methodological perspective. When the scale of the given math model is large and it is difficult or impossible to use exact algorithm, then heuristics algorithm would be suitable to search the near optimal solution instead. Metaheuristics (16\%) develop rapidly standing out from classical heuristics recently because of their computational effectiveness and general applicability. In other words, unlike classical heuristics, metaheuristics require much less work than developing a specialised heuristic for a specific problem. Metaheuristics have their standard mechanisms to guide the search from an initial solution set to near optimal solutions. Many problems can implement metaheuristics via using general purpose software. But it also means that the user must understand and specify their complicated mechanisms.

Three papers $(6 \%)$ use more than two classes of algorithm in their paper to solve or compare the solutions. Researchers can consider this approach if the problem is complex and achieving optimal results is their primary aim. Adopting hybrid approach has become more popular in recent years and is a rising trend since multi-objective optimisation and tackling larger scale practical problems as discussed above would increase the level of complexity.

Twenty-one (42\%) papers do not specify algorithms which is the most common approach. They use commercial software, for example, CPLEX and LINGO revealing such softwares' good performance in linear optimisation. Problem solving method 
benefits from the development of computer technology. Many optimisation softwares are updated and embedded with some common algorithms which become powerful optimisation platforms. This is considered as a positive phenomenon since such optimisation platforms can assist scholars using their models to optimise practical problems efficiently.

Table 5 Classification according to algorithms

\begin{tabular}{|c|c|c|}
\hline $\begin{array}{l}\text { Algorithm } \\
\text { classification }\end{array}$ & Papers (totally selected 50 papers) & Number $(\%)$ \\
\hline Exact algorithm & $\begin{array}{l}\text { 1, White (1972), 9, Cullinane et al. (2002), 12, Karimi } \\
\text { et al. (2005), 19, Jula et al. (2006), 23, Rahimi et al. } \\
\text { (2008), 29, Sun et al. (2009), 32, Liao et al. (2009). }\end{array}$ & $7(14 \%)$ \\
\hline Classical heuristics & $\begin{array}{l}\text { 5, Lai et al. (1995), 6, Shen and Khoong (1995), } \\
\text { 8, Newman and Yano (2000), 18, Coslovich et al. } \\
\text { (2006), 20, Imai et al. (2007), 34, Infante et al. (2009), } \\
\text { 42, Jula and Leachman (2011a), 43, Jula and } \\
\text { Leachman (2011b), 48, Davidson and Leachman } \\
\text { (2012). }\end{array}$ & $9(18 \%)$ \\
\hline Metaheuristics & $\begin{array}{l}\text { 4, Crainic et al. (1993b), 28, Caris and Janssens } \\
\text { (2009), 31, Imai et al. (2009), 35, Chen and Yang } \\
\text { (2010), 44, Meng and Wang (2011), 45, Wang and } \\
\text { Yun (2011), 47, Zhang et al. (2011), 50, Dang et al. } \\
\text { (2012). }\end{array}$ & $8(16 \%)$ \\
\hline Simulation & 30, Bandeira et al. (2009), 33, Francesco et al. (2009). & $2(4 \%)$ \\
\hline $\begin{array}{l}\text { No specified } \\
\text { algorithm just using } \\
\text { commercial software }\end{array}$ & $\begin{array}{l}\text { 2, Min (1991), 3, Crainic et al. (1993a), 7, Miller et al. } \\
\text { (1996), 10, Choong et al. (2002), 11, Jansen et al. } \\
\text { (2004), 13, Parola and Sciomachen (2005), 14, Erera et } \\
\text { al. (2005), 15, Olivo et al. (2005), 16, Cheang and Lim } \\
\text { (2005), 21, Wang and Wang (2007), 22, Deidda et al. } \\
\text { (2008), 24, Feng and Chang (2008), 26, Kim et al. } \\
\text { (2008), 27, Leachman (2008), 36, Fan et al. (2010), 37, } \\
\text { Iannone and Thore (2010), 38, Thill and Lim (2010), } \\
\text { 39, Fan et al. (2010), 41, Shintani et al. (2010), } \\
\text { 46, Yang et al. (2011), 49, Iannone (2012). }\end{array}$ & $21(42 \%)$ \\
\hline $\begin{array}{l}\text { With more than two } \\
\text { algorithm classes }\end{array}$ & $\begin{array}{l}\text { 17, Jula et al. (2005), 25, Chang et al. (2008), } \\
\text { 40, Zhang et al. (2010). }\end{array}$ & $3(6 \%)$ \\
\hline
\end{tabular}

\subsection{Discussion according to case study areas}

Table 6 is formulated to analyse the geographical locations of case studies in the selected papers. It is found that case studies centred around three major areas, namely Asia, North America and Europe. Major ports and maritime countries are located in these areas. It implies that research interest is driven by the demand for practical application.

To have a more thorough analysis, we continue to classify each area into countries and sub-regions. Although Mainland China and Taiwan are considered parts of China, they are differentiated in this paper because they have their own administrative independencies. Among the Asian countries and sub-regions, Mainland China might be a relatively popular sub-region in such optimisation issues, with five publications. It is not surprising that the world economy is affected by the 'China effect'. Many foreign 
corporations have relocated their production and distribution networks to Mainland China. The volume of intermodal freight movement in Mainland China has increased dramatically in recent years and would maintain a high growth rate in the following years. There are great potentials in China's distribution and logistics development (Frankel, 1998; Jiang and Prater, 2002; Lam and Yap, 2011b). However, there are only five research contributions using Mainland China as case study area to test the container flow optimisation model and algorithm among these 50 selected papers. There is also a pressing need for more research to be conducted for another fast growing country - India. Integrated intermodal transportation network which translates to high quality management of cargo flows with low inventory costs, more reliable delivery time and distribution will enhance Indian merchandises' competitiveness within the global market (Ng and Gujar, 2009). Only one container flow optimisation study has been done for India's case, thus presenting great potential for future research.

Concerning North America, USA is the most researched country (ten papers out of totally 12 papers). USA is a major trading nation with long coastline and extensive land bridge transportation infrastructures. Corresponding research for USA would continue to grow with higher sophistication. It would be interesting to model the port hinterland intermodal network in consideration of Panama Canal's upgrading work in future studies.

With respect to Europe, Italy might be the country with more case studies conducted (four papers out of 11) in such optimisation issues. There are many countries each with a small territory in the European continent. Six out of the 11 papers conducted case studies on container network optimisation relating to a large range of European area, not to an individual country owing to the territory limitation. Since European ports' hinterland involves more than one country in most cases, researching intermodal network with multiple countries aligns with such practical situation. This approach is also recommended for other regions with active or growing cross-border intermodal transport, for example, between China and Southeast Asia peninsula including countries like Vietnam and Thailand.

Table 6 Classification according to case study areas

\begin{tabular}{|c|c|c|c|}
\hline \multicolumn{2}{|c|}{ Case study area } & \multirow[t]{2}{*}{ Papers (totally selected 50 papers) } & \multirow{2}{*}{$\frac{\text { Number }(\%)}{16(32 \%)}$} \\
\hline 1 & Asia & & \\
\hline & Mainland China & $\begin{array}{l}\text { 9, Cullinane et al. (2002), 29, Sun et al. } \\
\text { (2009), 35, Chen and Yang (2010), 44, Meng } \\
\text { and Wang (2011), 46, Yang et al. (2011). }\end{array}$ & $5 / 16$ \\
\hline & Taiwan & 32, Liao et al. (2009). & $1 / 16$ \\
\hline & India & 46, Yang et al. (2011). & $1 / 16$ \\
\hline & Singapore & 16, Cheang and Lim (2005). & $1 / 16$ \\
\hline & Korea & 26, Kim et al. (2008). & $1 / 16$ \\
\hline & $\begin{array}{l}\text { No specified country or } \\
\text { sub-region just Asian area }\end{array}$ & $\begin{array}{l}\text { 5, Lai et al. (1995), 24, Feng and Chang } \\
\text { (2008), 27, Leachman (2008), 31, Imai et al. } \\
\text { (2009), 42, Jula and Leachman (2011a), } \\
\text { 43, Jula and Leachman (2011b), } \\
\text { 48, Davidson and Leachman (2012). }\end{array}$ & $7 / 16$ \\
\hline \multirow[t]{2}{*}{2} & North America & & $12(24 \%)$ \\
\hline & USA & $\begin{array}{l}\text { 10, Choong et al. (2002), 19, Jula et al. } \\
\text { (2006), 23, Rahimi et al. (2008), 25, Chang et }\end{array}$ & $10 / 12$ \\
\hline
\end{tabular}


al. (2008), 27, Leachman (2008), 38, Thill and Lim (2010), 39, Fan et al. (2010), 42, Jula and Leachman (2011a), 43, Jula and Leachman (2011b), 48, Davidson and Leachman (2012).

No specified country just 7, Miller et al. (1996), 31, Imai et al. (2009). North America area

Table 6 Classification according to case study areas (continued)

\begin{tabular}{|c|c|c|c|}
\hline \multicolumn{2}{|c|}{ Case study area } & \multirow[t]{2}{*}{ Papers (totally selected 50 papers) } & \multirow{2}{*}{$\frac{\text { Number }(\%)}{11(22 \%)}$} \\
\hline 3 & Europe & & \\
\hline & Netherlands & 11, Jansen et al. (2004). & $1 / 11$ \\
\hline & Italy & $\begin{array}{l}\text { 13, Parola and Sciomachen (2005), } \\
\text { 18, Coslovich et al. (2006), 37, Iannone and } \\
\text { Thore (2010), 49, Iannone (2012). }\end{array}$ & $4 / 11$ \\
\hline & $\begin{array}{l}\text { No specified country just } \\
\text { European area }\end{array}$ & $\begin{array}{l}\text { 5, Lai et al. (1995), 15, Olivo et al. (2005), } \\
\text { 31, Imai et al. (2009), 33, Francesco et al. } \\
\text { (2009), 36, Fan et al. (2010), 41, Shintani } \\
\text { et al. (2010). }\end{array}$ & $6 / 11$ \\
\hline 4 & No specified area & $\begin{array}{l}\text { 1, White (1972), 2, Min (1991), 3, Crainic } \\
\text { et al. (1993a), 4, Crainic et al. (1993b), } \\
\text { 6, Shen and Khoong (1995), 8, Newman and } \\
\text { Yano (2000), 12, Karimi et al. (2005), } \\
\text { 14, Erera et al. (2005), 17, Jula et al. (2005), } \\
\text { 20, Imai et al. (2007), 21, Wang and Wang } \\
\text { (2007), 22, Deidda et al. (2008), 28, Caris } \\
\text { and Janssens (2009), 30, Bandeira et al. } \\
\text { (2009), 34, Infante et al. (2009), 40, Zhang et } \\
\text { al. (2010), 45, Wang and Yun (2011), } \\
\text { 47, Zhang et al. (2011), 50, Dang et al. } \\
\text { (2012). }\end{array}$ & $19(38 \%)$ \\
\hline
\end{tabular}

\subsection{Further discussion on green concerns and research directions}

When Tables 3 and 6 are analysed together, among the scant literature with environmental concerns (eight papers), three studied the case of USA, one studied about Europe and one was about Taiwan and the other thee did not specify any region. There is no application on the two fast growing economic giants - China and India. As discussed above, more research should be devoted to study intermodal development in these two countries. China and India's speedy economic growths, huge potential demands for consumption and ever-rising pressure from the global production and distribution, have all granted a strong support for the development of their transportation and logistics industries, including the port intermodal development due to their wide hinterland ranges. Nevertheless, pollution would also be increased with such rapid growth in economic development and transport volume. Intermodal development offers great potential to improve sustainability because railway and inland barge transport incurs much lower carbon emissions than trucking which is now dominant in inland transport (Rahimi et al., 2008; Liao et al., 2009; Shintani et al., 2010). 
In addition to the suggestions in the previous sections, we recommend more scientific research to be conducted on sustainable port hinterland intermodal development in order to fulfil the industry needs. In particular, the identified research gap 'Intermodal container flow considering both empty and laden containers with green concern using multi-objective optimisation' can be explored for China, India and other countries especially with large continent. For example, given the closer scrutiny on the environmental performance of the transport sector, optimisation model can be developed to consider the various carbon footprint restriction scenarios for the planning of intermodal container flows. Such model can achieve optimal cost and transit time given a certain level of carbon emission requirement suggesting the most desirable modal split. Sensitivity analysis can be done to find out the effect on cost and time with tighter carbon emission control. To plan intermodal development and monitor its environmental impact, the change in carbon emission generated by the transport network can also be modelled in relation to infrastructure expansion and cargo volume growth. There is no research effort made in these topics so far according to the published research papers. It would be meaningful and beneficial if future studies can fill up this research gap to address the challenges for various countries' port hinterland development.

\section{Practical significance and conclusions}

In this original review paper, totally 50 earlier research articles on intermodal container flow optimisation issues which are published between 1972 and 2012 with 40 years' time span are selected and examined. Our contributions are twofold: firstly, we build an overall summary table (Table 1) and relevant sub-tables (from Table 2 to Table 6) to provide a structured and classified review and insightful analysis on the growing and contemporary subject of container transport optimisation; secondly, through such tables and detailed analyses from various perspectives, the trends and gaps in this research area are identified and future research directions are suggested accordingly, and thereby assisting scientific and practical efforts in port hinterland intermodal development.

Future research should focus on global intermodal container flow optimisation, involving both laden containers and empty containers taken green issues into account, addressing the approaches of port integrating into such global intermodal chain. Research concerning environmental impacts is progressively increasing but inadequate. There is substantial need for research addressing greening the intermodal network and sustainable development. We discover that providing cost effective solutions alone in optimisation problem is rather traditional and one-sided. In practice nowadays, those market players possessing commercially viable capabilities and also environmental responsibilities would gain a competitive advantage in future dynamic business environment. Multi-objective optimisation would be more suitable to actual situations. Our findings and suggestions would guide intermodal transport operators and integrators in their network design.

Relating to case study areas, the identified research gaps in this article would be explored for China, India and regions with intermodal network involving multiple countries. It would be beneficial if future studies can address the pressing demand for the emerging countries' port hinterland development. It would also be interesting to analyse the effects brought by upcoming changes such as the upgrading of the Panama Canal. Optimisation and simulation models not only aid tactical and operational planning, but 
also intermodal infrastructure development and policy making. Through quantifying commercial and environmental impacts, more optimal intermodal transport network can be planned and built according to the desirable economic objectives and environmental performance. Correspondingly, intermodal development will affect the industry and market players due to, for example, the number of concessions granted by the government to truckers, rail operators, barge operators and dry port operators. Such strategic decisions should be supported by analytical tools rather than by intuition only. In this paper, observations in research methodology and algorithm classifications have also been drawn. In short, adopting hybrid approach in combining two algorithms in one problem could be an uprising tendency since multi-objective optimisation and tackling larger scale practical problems as discussed above would increase the level of complexity. Therefore, this review serves as a practical guide assisting future efforts in developing analytical tools.

As a whole, the paper has provided a comprehensive review of earlier research contributions in a growing and contemporary subject. The insightful analysis in Section 3 helps channel future research efforts along the identified paths to be both practical and forward-looking. While endeavours were carried to be all-inclusive and holistic, same as other literature review studies, some research activities and efforts might have been unconsciously neglected. However, this review paper should be a comprehensive representation of the body of research on intermodal container transport optimisation published in international outlets during the specified time span.

Before closing this paper, we would like to highlight the ongoing opportunity for the development of global intermodal container network approaches and related studies including supply chain and policy perspectives in the future. Issues such as the surge of port-hinterland container transportation flows in major exporting/importing countries, the shortage of corresponding infrastructure capacity and environmental concerns about the emission of greenhouse gas are up and coming. If there is a potential that someone would be the leader in supply chain integration between sea and land transportation, the seaport could have a try to play the leading role by its unique status. It has the natural feature as the interface between the sea and the land. Port regionalisation concept gives seaports opportunities to realise the complex and dynamic integration especially focusing on container transportation flows. This integration's objective should be versatile in coping with supply chain dynamics. Multiple factors along the supply chain including economic, social and environmental aspects are very important to be considered. Trying to find and deal with the trade-offs among these multi-objectives would be paramount and can be achieved by the reviewed mathematical models in future research.

\section{Acknowledgements}

We thank the anonymous reviewers for their valuable comments and suggestions.

\section{References}

Almotairi, B. and Lumsden, K. (2009) 'Port logistics platform integration in supply chain management', International Journal of Shipping and Transport Logistics, Vol. 1, No. 2, pp.194-210. 
Bandeira, D.L., Becker, J.L. and Borenstein, D. (2009) 'A DSS for integrated distribution of empty and full containers', Decision Support Systems, Vol. 47, No. 4, pp.383-397.

Barnhart, C. and Laporte, G. (2007) Intermodal Transportation, Elsevier, North-Holland, Amsterdam.

Bichou, K. and Gray, R. (2004) 'A logistics and supply chain management approach to port performance measurement', Maritime Policy \& Management, Vol. 31, No. 1, pp.47-67.

Bontekoning, Y.M., Macharis, C. and Trip, J.J. (2004) 'Is a new applied transportation research field emerging? - A review of intermodal rail-truck freight transport literature', Transportation Research Part A: Policy and Practice, Vol. 38, No. 1, pp.1-34.

Carbone, V. and Martino, M.D. (2003) 'The changing role of ports in supply-chain management: an empirical analysis', Maritime Policy \& Management, Vol. 30, No. 4, pp.305-320.

Caris, A. and Janssens, G.K. (2009) 'A local search heuristic for the pre- and end-haulage of intermodal container terminals', Computers \&Operations Research, Vol. 36, No. 10, pp.2763-2772.

Chang, H., Jula, H., Chassiakos, A. and Ioannou, P. (2008) 'A heuristic solution for the empty container substitution problem', Transportation Research Part E, Vol. 44, No. 2, pp.203-216.

Cheang, B. and Lim, A. (2005) 'A network flow based method for the distribution of empty containers', International Journal of Computer Applications in Technology, Vol. 22, No. 4, pp.198-204.

Chen, G. and Yang, Z. (2010) 'Optimizing time windows for managing export container arrivals at Chinese container terminals', Maritime Economics \& Logistics, Vol. 12, No. 1,pp.111-126.

Choong, S.T., Cole, M.H. and Kutanoglu, E. (2002) 'Empty container management for intermodal transportation networks', Transportation Research Part E, Vol. 38, No. 6, pp.423-438.

Coslovich, L., Pesenti, R. and Ukovich, W. (2006) 'Minimizing fleet operating costs for a container transportation company', European Journal of Operational Research, Vol. 171, No. 3, pp.776-786.

Crainic, T.G., Gendreau, M. and Dejax, P. (1993a) 'Dynamic and stochastic models for the allocation of empty containers', Operations Research, Vol. 41, No. 1, pp.102-126.

Crainic, T.G., Gendreau, M., Soriano, P. and Toulouse, M. (1993b) 'A tabu search procedure for multicommodity location/allocation with balancing requirements', Annals of Operations Research, Vol. 41, No. 4, pp.359-383.

Cullinane, K., Ping, J. and Wang, T-F. (2002) 'A multi-objective programming approach to the optimization of China's international container transport network', International Journal of Transport Economics, Vol. 29, No. 2, pp.181-199.

Dang, Q-V., Yun, W-Y. and Kopfer, H. (2012) 'Positioning empty containers under dependent demand process', Computers \& Industrial Engineering, Vol. 62, No. 3, pp.708-715.

Davidson, E.T. and Leachman, R.C. (2012) 'Optimizing a multi-strategy port and modal allocation of containerized imports from Asia to the United States', Journal of Marketing Channels, Vol. 19, No. 2, pp.120-140.

Deidda, L., Francesco, M.D., Olivo, A. and Zuddas, P. (2008) 'Implementing the street-turn strategy by an optimization model', Maritime Policy \& Management, Vol. 35, No. 5, pp.503-516.

Eng-Larsson, F. and Kohn, C. (2012) 'Modal shift for greener logistics - the shipper's perspective', International Journal of Physical Distribution \& Logistics Management, Vol. 42, No. 1, pp.36-59.

Erera, A.L., Morales, J.C. and Savelsbergh, M. (2005) 'Global intermodal tank container management for the chemical industry', Transportation Research Part E, Vol. 41, No. 6, pp.551-566.

Fan, L., Wilson, W.W. and Tolliver, D. (2010) 'Optimal network flows for containerized imports to the United States', Transportation Research Part E, Vol. 46, No. 5, pp.735-749. 
Feng, C-M. and Chang, C-H. (2008) 'Empty container reposition planning for intra-Asia liner shipping', Maritime Policy \& Management, Vol. 35, No. 5, pp.469-489.

Francesco, M.D., Crainic, T.G. and Zuddas, P. (2009) 'The effect of multi-scenario policies on empty container repositioning', Transportation Research Part E, Vol. 45, No. 5, pp.758-770.

Frankel, E.G. (1998) 'China's maritime developments', Maritime Policy \& Management, Vol. 25, No. 3, pp.235-249.

Fremont, A. and Géographie, A.D. (2009) 'Empirical evidence for integration and disintegration of maritime shipping, port and logistics activities', in International Transport Forum \& OECD (Organisation for Economic Co-operation and Development), 2009 January, OECD publishing, pp.1-33.

Harrington, L.H. (1991) 'Landlocked shippers use inland port', Transportation\&Distribution, Vol. 32, No. 10, p.82.

Hayutha, Y. (1991) 'Load centering competition and modal integration', Coastal Management, Vol. 19, No. 3, pp.297-311.

Iannone, F. (2012) 'A model optimizing the port-hinterland logistics of containers: the case of the Campania Region in southern Italy', Maritime Economics \& Logistics, Vol. 14, No. 1, pp.33-72.

Iannone, F. and Thore, S. (2010) 'An economic logistics model for the multimodal inland distribution of maritime containers', International Journal of Transport Economics, Vol. 37, No. 3, pp.281-326.

Imai, A. and Rivera, F. (2001) 'Strategic fleet size planning for maritime refrigerated containers', Maritime Policy \& Management, Vol. 28, No. 4, pp.361-374.

Imai, A., Nishimura, E. and Current, J. (2007) 'A lagrangian relaxation-based heuristic for the vehicle routing with full container load', European Journal of Operational Research, Vol. 176, No. 1, pp.87-105.

Imai, A., Shintani, K. and Papadimitriou, S. (2009) 'Multi-port vs. Hub-and-Spoke port calls by containerships', Transportation Research Part E, Vol. 45, No. 5, pp.740-757.

Infante, D., Paletta, G. and Vocaturo, F. (2009) 'A ship-truck intermodal transportation problem', Maritime Economics \& Logistics, Vol. 11, No. 3, pp.247-259.

Jansen, B., Swinkels, P.C.J., Teeuwen, G.J.A., Fluiter, B.V.a.D. and Fleuren, H.A. (2004) 'Operational planning of a large-scale multi-modal transportation system', European Journal of Operational Research, Vol. 156, No. 1, pp.41-53.

Jiang, B. and Prater, E. (2002) 'Distribution and logistics development in China: the revolution has begun', International Journal of Physical Distribution \& Logistics Management, Vol. 32, No. 9, pp.783-798.

Jula, H., Chassiakos, A. and Ioannou, P. (2006) 'Port dynamic empty container reuse', Transportation Research Part E, Vol. 42, No. 1, pp.43-60.

Jula, H., Dessouky, M., Ioannou, P. and Chassiakos, A. (2005) 'Container movement by trucks in metropolitan networks: modeling and optimization', Transportation Research Part E, Vol. 41, No. 3, pp.235-259.

Jula, P. and Leachman, R.C. (2011a) 'Long- and short-run supply-chain optimization models for the allocation and congestion management of containerized imports from Asia to the United States', Transportation Research Part E, Vol. 47, No. 5, pp.593-608.

Jula, P. and Leachman, R.C. (2011b) 'A supply-chain optimization model of the allocation of containerized imports from Asia to the United States', Transportation Research Part E, Vol. 47, No. 5, pp.609-622.

Karimi, I.A., Sharafali, M. and Mahalingam, H. (2005) 'Scheduling tank container movements for chemical logistics', Aiche Journal, Vol. 51, No. 1, pp.178-197.

Kim, H-J., Chang, Y-T., Lee, P.T-W., Shin, S-H. and Kim, M-J. (2008) 'Optimizing the transportation of international container cargoes in Korea', Maritime Policy \& Management, Vol. 35, No. 1, pp.103-122. 
Lai, K.K., Lam, K. and Chan, W.K. (1995) 'Shipping container logistics and allocation', Jounal of the Operational Research Society, Vol. 46, No. 6, pp.687-697.

Lam, J.S.L. and Yap, W.Y. (2011a) 'Dynamics of liner shipping network and port connectivity in supply chain systems: analysis on East Asia', Journal of Transport Geography, Vol. 19, No. 6, pp.1272-1281.

Lam, J.S.L. and Yap, W.Y. (2011b) 'Container port competition and complementarity in supply chain systems: evidence from the Pearl River Delta', Maritime Economics and Logistics, Vol. 13, No. 2, pp.102-120.

Leachman, R.C. (2008) 'Port and modal allocation of waterborne containerized imports from Asia to the United States', Transportation Research Part E, Vol. 44, No. 2, pp.313-331.

Lee, E-S. and Song, D-W. (2008) 'Lean organization: a new direction for ports in global logistics', Journal of International Logistics and Trade, Vol. 6, No. 1, pp.75-95.

Liao, C-H., Tseng, P-H. and Lu, C-S. (2009) 'Comparing carbon dioxide emissions of trucking and intermodal container transport in Taiwan', Transportation Research Part D, Vol. 14, No. 7, pp.493-496.

Macharis, C. and Bontekoning, Y.M. (2004) 'Opportunities for OR in intermodal freight transport research: a review', European Journal of Operational Research, Vol. 153, No. 2, pp.400-416.

Marlow, P.B. and Paixao, A.C. (2003) 'Measuring lean ports performance', International Journal of Transport Management, Vol. 1, No. 4, pp.189-202.

Meng, Q. and Wang, X. (2011) 'Intermodal hub-and-spoke network design: incorporating multiple stakeholders and multi-type containers', Transportation Research Part B, Vol. 45, No. 4, pp.724-742.

Miller, T., Wise, D. and Clair, L. (1996) 'Transport network design and mode choice modeling for automobile distribution: a case study', Location Science, Vol. 4, Nos. 1-2, pp.37-48.

Min, H. (1991) 'International intermodal choices via chance-constrained goal programming', Transportation Research Part A: Policy and Practice, Vol. 25, No. 6, pp.351-362.

Newman, A.M. and Yano, C.A. (2000) 'Scheduling direct and indirect trains and containers in an intermodal setting', Transportation Science, Vol. 34, No. 3, pp.256-270.

Ng, A.K.Y. and Gujar, G.C. (2009) 'Government policies, efficiency and competitiveness: the case of dry ports in India', Transport Policy, Vol. 16, No. 5, pp.232-239.

Notteboom, T.E. and Rodrigue, J-P. (2005) 'Port regionalization: towards a new phase in port development', Maritime Policy \& Management, Vol. 32, No. 3, pp.297-313.

Notteboom, T.E. and Rodrigue, J-P. (2008) 'Containerisation, box logistics and global supply chains: the integration of ports and liner shipping networks', Maritime Economics \& Logistics, Vol. 10, Nos. 1-2, pp.152-174.

Olivo, A., Zuddas, P., Francesco, M.D. and Manca, A. (2005) 'An operational model for empty container management', Maritime Economics \& Logistics, Vol. 7, No. 3, pp.199-222.

Paixao, A.C. and Marlow, P.B. (2003) 'Fourth generation ports - a question of agility?', International Journal of Physical Distribution \& Logistics Management, Vol. 33, No. 4, pp.355-376.

Parola, F. and Sciomachen, A. (2005) 'Intermodal container flows in a port system network: analysis of possible growths via simulation models', International Journal of Production Economics, Vol. 97, No. 1, pp.75-88.

Rahimi, M., Asef-Vaziri, A. and Harrison, R. (2008) 'An inland port location-allocation model for a regional intermodal goods movement system', Maritime Economics \& Logistics, Vol. 10, No. 4, pp.362-379.

Rodrigue, J-P. and Notteboom, T.E. (2009) 'The terminalization of supply chains: reassessing the role of terminals in port/hinterland logistical relationships', Maritime Policy \& Management, Vol. 36, No. 2, pp.165-183.

Roso, V. and Lumsden, K. (2010) 'A review of dry ports', Maritime Economics \& Logistics, Vol. 12, No. 2, pp.196-213. 
Shen, W.S. and Khoong, C.M. (1995) 'A DSS for empty container distribution planning', Decision Suport Systems, Vol. 15, No. 1, pp.75-82.

Shintani, K., Konings, R. and Imai, A. (2010) 'The impact of foldable containers on container fleet management costs in hinterland transport', Transportation Research Part E, Vol. 46, No. 5, pp.750-763.

Sun, M., Wang, X., Chen, X. and Cao, L. (2009) 'Study on empty container repositioning problem under sea-rail through transport', in Second International Conference on Intelligent Computation Technology and Automation, 2009 October, Changsha, China, IEEE Computer Society, pp.771-774.

Thill, J-C. and Lim, H. (2010) 'Intermodal containerized shipping in foreign trade and regional accessibility advantages', Journal of Transport Geography, Vol. 18, No. 4, pp.530-547.

Walter, C.K. and Poist, R.F. (2003) 'Desired attributes of an inland port-shipper vs carrier perspectives', Transportation Journal, Vol. 42, No. 5, pp.42-55.

Walter, C.K. and Poist, R.F. (2004) 'North American inland port development international vs domestic shipper preferences', International Journal of Physical Distribution \& Logistics Management, Vol. 34, No. 7, pp.579-597.

Wang, B. and Wang, Z. (2007) 'Research on the optimization of intermodal empty container reposition of land-carriage', Journal of Transportation Systems Engineering and Information Technology, Vol. 7, No. 3, pp.29-33.

Wang, W.F. and Yun, W.Y. (2011) 'Scheduling for inland container truck and train transportation', International Journal of Production Economics, in press, corrected proof.

White, W.W. (1972) 'Dynamic transshipment networks: an algorithm and its application to the distribution of empty containers', Networks, Vol. 2, No. 3, pp.211-236.

Yang, X., Low, J.M.W. and Tang, L.C. (2011) 'Analysis of intermodal freight from China to Indian ocean: a goal programming approach', Journal of Transport Geography, Vol. 19, No. 4, pp.515-527.

Yang, X-S. (2008) Introduction to Mathematical Optimization: From Linear Programming to Metaheuristics, Cambridge International Science Publishing, Cambridge, UK.

Yap, W.Y., Lam, J.S.L. and Notteboom, T. (2006) 'Developments in container port competition in East Asia', Transport Reviews, Vol. 26, No. 2, pp.167-188.

Zhang, R., Yun, W.Y. and Kopfer, H. (2010) 'Heuristic-based truck scheduling for inland container transportation', OR SPECTRUM, Vol. 32, No. 3, pp.787-808.

Zhang, R., Yun, W.Y. and Moon, I.K. (2011) 'Modeling and optimization of a container drayage problem with resource constraints', International Journal of Production Economics, Vol. 133, No.1, pp.351-359. 